\title{
Media Literacy for Kindergarten Teacher in Assisting Students to Learn via Gadgets from and at Home
}

\author{
Muchammad Yuliyanto ${ }^{1}$, Hedi Pudjo Santosa ${ }^{2}$, Primada Qurrota Ayun ${ }^{3}$, Nuriyatul Lailiyah ${ }^{4}$, \\ Sri Budi Lestari ${ }^{5}$ \\ \{m.yuliyanto@yahoo.com ${ }^{1}$ \} \\ Universitas Diponegoro, Indonesia ${ }^{1,2,3,4,5}$
}

\begin{abstract}
Covid-19 pandemic forces everyone in the world to change lifestyle dramatically, including our education system. Teachers, parents, and students in kindergarten are required to do teaching and learning activities from and at home for quite a long period. Children in kindergarten who are ideally very limited in their gadget consumption now have more access to gadgets due to parents' burden in running the house and working from home. As the teacher also become parents, they face a double burden in teaching someone else's children and children of their own. This research is the result of our community service activity to the teachers of kindergarten in Semarang by online meetings via group WhatsApp and zoom. It is aimed to evaluate the shift of understanding and attitude of the teachers regarding the use of gadgets and the learn from home activities before and after treatment. The treatment was intended to change the understanding and attitude of the teachers to be more positive in assisting and facilitating the kindergarten students to learn from home.
\end{abstract}

Keywords: Kindergarten, Teacher, Media Literacy, Learn from Home

\section{Introduction}

The world of education in the industrial revolution era entered the knowledge age with an extraordinary increase in knowledge. The acceleration of increasing knowledge is supported by the application of media and digital technology called the information superhighway [1].

Launching a white paper published by the World Economic Forum (WEF) in January 2020, the world currently needs the Education 4.0 method to support The Fourth Industrial Revolution. In the white paper, eight critical characteristics were mentioned in the content and learning experience for implementing Education 4.0.

These eight characteristics include the ability of the global community, the ability to innovate and be creative, technological skills, interpersonal skills, and personalized learning according to individual characteristics (personalized and self-paced learning). Furthermore, there is inclusive learning, problem-based and collaborative learning, and lifelong learning according to student needs (lifelong and student-driven learning).

At this time the world is facing the Coronavirus pandemic which results in changes to the online learning system. The learning process is carried out online. This policy "forces" the schools, educators, students, parents to be "technology literate". Educators are required to carry out an online learning process. This means having to master the strategies, methods, development of online learning. Besides, it is more important to master the applications used. 
The obstacles faced by the implementation of online learning are still many educators who do not master ICT.

Likewise, the challenges for students are not ready to carry out the online learning process. In addition to the limited availability of facilities and infrastructure, online learning applications have not been accustomed to so that they are "forced" to use applications that are often used.

Likewise, parents feel the impact of this online learning more. Parents are "forced" to become educators who accompany their children in the learning process. Parents begin to feel how difficult it is to be educators, and there are many more complaints they face.

Teachers must understand how to use media and need to understand what media literacy is. Media literacy, according to Aufderheide [2] identifies as a movement, which is designed to help understand, produce and negotiate meaning in the culture of images, words, and sounds.

This research is a community service activity based carried out by the team by conducting online socialization through the WhatsApp group and zoom. This research was conducted by evaluating the attitudes and knowledge of kindergarten teachers before and after treatment. Treatment is aimed at changing the knowledge and attitude of the object, in this case, PAUD teachers, to be more positive in assisting children to learn through gadgets at home.

School was chosen with the consideration that it is located in one city so that it become a priority in community service. In addition, the new situation in online learning will be more challenging for teachers at the kindergarten level compared to higher education levels such as elementary, junior high, high school, and college students.

\section{Result and Discussion}

The post-survey showed that the information dissemination carried out by the team went well and succeeded in strengthening participants' knowledge and positive attitudes regarding online learning.

All participants $(100 \%)$ stated that learning materials during the pandemic must be made more flexible and lighter than normal situations. Given that everyone is making adjustments to adapt to the pandemic situation.

Apart from the questionnaires answered by the participants, participants also submitted their questions and opinions regarding learning activities from home during the pandemic. Participants find it difficult to meet the learning outcomes that have been set. Apart from that, many technical obstacles arise in terms of parents, children, and teachers themselves. Limitations of gadgets, quotas, working parents, and children's mood to study at home are problems that make learning from home more challenging. This is in line with the findings of similar research [3] which states that the network is one of the technical problems. Besides that, the motivation of teachers and students is also a problem. This reinforces that the problem of learning from home is relatively uniform, mainly due to our unawareness and unfamiliarity with this situation before anything further such as the availability of gadgets, etc.

"One's knowledge of media literacy - the ability to decode, evaluate, analyze, and produce both print and electronic media. The fundamental aim of media literacy is an important autonomous relationship for all media. The emphasis in media literacy training ranges widely, including citizenship of information, appreciation of aesthetics and expression, social advocacy, self-esteem, and consumer competence" [4].

The main concepts that can be conveyed to children in media education are as follows [5]: 
1. Messages are constructions. The message is the result of construction, that the media is not a simple reflection of external reality. Media messages are the product of a very careful creation as a result of several considerations and external determinants.

2. Media messages are constructed using a creative language with its own rules. Media messages use a system of symbols, music, narration, and digital processing to create certain effects on the audience.

3. Audiences actively interpret messages. People construct meaning when they consume media. The interpretation of the message varies depending on individual factors, such as level of development, personal needs, and so on.

4. Media have embedded values and points of view. Explicitly or implicitly, the media express certain ideologies by presenting certain perspectives, values, and attitudes in what they broadcast.

5. The media have commercial implications and exist with an economic context. Media literacy aims to provide awareness of how media content is influenced by commercial, political, and other interests.

Online learning changes how teachers who used to explain in class now face two situations. Must teach their students from home as well as accompany their children to study at home. All use gadgets.

The research results show that teachers experience anxiety and find it difficult to teach. Children who do not focus when learning with gadgets, working parents so that they cannot lend their cellphones during school hours are problems that many teachers feel.

In this service activity, the research team said that basically, teachers need to lower the standards they set so that they can be more flexible in facing the diverse and challenging learning situations of kindergarten students. Given that very large adjustments also occur in general in the world of education, including at higher levels of education.

Some things that teachers should keep in mind during the pandemic and home study times are:

First, teachers need to reduce the workload given to children compared to normal situations. Like adults, children also have problems adjusting to life during the pandemic. Children who used to be able to meet friends at school, a religious school in the afternoon, and play with their friends freely, suddenly have a lot to be in the house.

Second, teachers need to provide leeway regarding technical matters and assignment collection. Parents who work, take care of the house, and at the same time, assist school children in a large and complex job. So that often it takes more time than usual to assist children in carrying out tasks.

Third, teachers need to give parents the freedom to interpret the child's assignment application as long as learning objectives are achieved. Parents need to have flexibility in translating assignments for their children. Given the instructions given by the teacher is only online and there is a very open space for interpretation that is tailored to the abilities of parents and the conditions they face at home.

Fourth, teachers need to understand that technical (such as network, internet quota, etc.) and non-technical obstacles (such as children refusing to learn, etc.) are very likely to occur.

Fifth, teachers should not only think about their role as teachers but also as parents. So that it is expected to be more empathetic when giving assignments.

Sixth, it is necessary to provide assignments that require fathers to be involved so that fathers can contribute to assisting children to learn from home.

The explanation from the research team to the teachers participating in community service activities was able to make teachers better understand the learning situations they had to face 
with the help of gadgets and parents at home. Teachers feel more prepared for child-friendly learning situations and do their best to ensure that neither party feels overwhelmed and achieves more realistic learning goals.

\section{Conclusion}

Distance learning online is a huge challenge for both educators and students. Apart from technical issues such as quotas, gadgets, signals, in general, we are more used to direct learning. At the kindergarten level, the problem will get bigger considering that children have not been able to learn with maximum focus even on direct learning.

The results showed that kindergarten teachers experienced difficulties especially because of the learning outcomes that had been set at the beginning with challenging conditions that occurred during online learning. Kindergarten children who must always be accompanied by their parents, the problem of working parents, refusing to go to school and doing assignments, and teachers who are also parents of children go to school, making online schools more complex.

In the end, in a pandemic like this time, it takes all parties' leniency to update standards and achievements that are more in line with the conditions of all parties involved, from students, parents, and teachers.

\section{References}

[1] V. Purcell-Gates, "Stories, coupons, and the TV Guide: Relationships between home literacy experiences and emergent literacy knowledge," Read. Res. Q., vol. 31, no. 4, pp. 406-428, 1996.

[2] P. Aufderheide, “Aspen media literacy conference report-part II: Proceedings and next steps," Washington, DC Aspen Inst., 1992.

[3] R. R. Aliyyah, R. Rachmadtullah, A. Samsudin, E. Syaodih, M. Nurtanto, and A. R. S. Tambunan, "The perceptions of primary school teachers of online learning during the COVID19 pandemic period: A case study in Indonesia," J. Ethn. Cult. Stud., vol. 7, no. 2, pp. 90-109, 2020.

[4] P. Aufderheide, Media Literacy. A Report of the National Leadership Conference on Media Literacy. ERIC, 1993.

[5] B. A. Lear, "Encyclopedia of Children, Adolescents, and the Media," Ref. User Serv. Q., vol. 47, no. 3, p. 286, 2008. 